Research Article

\title{
Sociodemographic profile of people attending integrated counselling and testing centre of tertiary care hospital of Jharkhand
}

\author{
Shamim Haider, Luguram Tudu*, Vivek Kashyap
}

Department of Preventive and social medicine, RIMS, Ranchi, Jharkhand, India

Received: 17 November 2015

Accepted: 18 December 2015

\section{*Correspondence:}

Dr. Luguram Tudu,

E-mail: drluguramtudu@gmail.com

Copyright: (C) the author(s), publisher and licensee Medip Academy. This is an open-access article distributed under the terms of the Creative Commons Attribution Non-Commercial License, which permits unrestricted non-commercial use, distribution, and reproduction in any medium, provided the original work is properly cited.

\begin{abstract}
Background: ICTC is the place where HIV symptomatic patients first come in contact with government health facility. Their seropositivity status depends the services which they will be provided in ICTC. The aim and objective of the study was Sociodemographic Profile and reason for attending Integrated Counseling and Testing Centre of Tertiary Care Hospital of Jharkhand.

Methods: A cross sectional, institutional based study was conducted at ICTC of Rims, Ranchi, Jharkhand. Total 116 subjects were included in the study. Pre tested, semi structured questionnaire were used for data collection. Data entry was done in MS excel and analysed in SPSS software.

Results: Out of 116 attendee majority were male (68.1\%), unmarried (56\%), Hindu (56.9\%), non tribal $(65.5 \%)$, graduate $(40.5 \%)$ and belonged to age group of $26-35$ years of age $(42.2 \%)$.

Conclusions: Intense IEC activities regarding spread and prevention from HIV/AIDS and behavioral changes is necessary.
\end{abstract}

Keywords: Behavioral changes, HIV, ICTC, IEC, Socio-demographic

\section{INTRODUCTION}

Integrated counselling and testing centre (ICTC) for HIV is a cost-effective intervention in preventing the spread of HIV transmission and is an integral part of HIV prevention program, which provides an opportunity to learn and accept the HIV status in a comfortable, convenient, and confidential manner. ${ }^{1}$ Integrated counselling testing center (ICTC) network is the first interface between a person willing to get tested and the public health system. ${ }^{2}$ The ICTC is an ideal point for prevention, where HIV negative individuals learn to use full array of existing services and interventions to adopt and maintain risk reduction behaviours, and HIV positive individuals use quality prevention services to adopt and sustain lifelong protective behaviours and avoid the virus transmission.
HIV continues to be a major global health issue, having claimed 34 million lives so far. In 20141.2 million people died from HIV related cause globally. It is estimated that currently only $51 \%$ of people with HIV know their status. ${ }^{4}$ In India HIV prevalence have declined in some state but rising trend is seen in also some state. This change in trend is because of migration and practicing high risk behavior and spreading of HIV infection to the general population ${ }^{5}$. This present study may help in understand the epidemiology of disease in the specific geographical region therefore this study was undertaken to study socio demographic profile of people and reason for attending Integrated Counselling and testing centre (ICTC) of Tertiary Care Hospital of Jharkhand. 


\section{METHODS}

The present cross sectional, institutional based study was conducted in ICTC in RIMS, Ranchi which is attached to Microbiology department. The Rajendra Institute of Medical Sciences (RIMS) is an apex institute of Jharkhand where patients are referred from whole Jharkhand and different department of the RIMS. Participant attended the ICTC centre by self-referral or referral by health care provider. This study was conducted between March 2015 - May 2015. Approximately ten patients are visit ICTC centre for getting tested. A Pre tested, semi structured questionnaire was used for patients interview.

During study period 116 attendee were registered and interviewed. Consecutive sampling was adopted. During study period data was collected on three days (alternate) days of every week. Days of data collection was changed on next consecutive week to avoid bias for day specific attendance. Every first five patients on that day were interviewed. If patient not found eligible next patients is interviewed. Patients less than 16 years of age, non willing, patients unable to communicate and seriously ill were excluded. Data was entered in MS excel and analysis was done by SPSS version 20. Ethical clearance was taken from departmental ethical committee to conduct the study.

\section{RESULTS}

There were $79(68.1 \%)$ males and $37(31.9 \%)$ female subject in the present study. Of 116 subjects 49 (42.2\%) were in the age group of 26-35 years. More than half of study subject belongs to urban $(60.3 \%)$ locality. About 66 $(56.9 \%)$ were Hindu and only few were Muslim 10 (8.6\%).Among all study subject $40(34.5 \%)$ were tribal whereas remaining $76(65.5 \%)$ were non-tribal. Majority were unmarried $65(56.0 \%)$. Among 116 subject 13 $(11.2 \%)$ were illiterate and less than half $47(40.5 \%)$ were educated up to graduation and above. Out of 116 subject $33(28.5 \%)$ were in service, $32(27.6 \%)$ were students, 20 $(17.2 \%)$ were daily wage earner, $16(13.8 \%)$ were house wife, $10(8.6 \%)$ were doing business and $5(4.3 \%)$ were farmer. Maximum subjects belonged to class III (28.4\%) followed by class II 26 (22.4\%), class I 25 (21.6\%), class IV $21(18.1 \%)$ and class V $11(9.5 \%)$.

The most common reason for visiting ICTC was (51, $44 \%$ ) of because of HIV related symptom. About 26 $(22.4 \%)$ were referred of their STI related symptom. 12 $(10.3 \%)$ just wanted to know their HIV infection status. Other reason for getting tested were husband/wife/partner/family member tested positive (10, $8.7 \%)$, employment $(7,6 \%)$, to prepare for a marriage/sexual relationship $(6,5.2 \%)$, pregnancy $(4$, $3.4 \%$ ) (Table 2).
Table 1: Selected socio-demographic profile of respondent $(n=116)$.

\begin{tabular}{|c|c|c|c|}
\hline \multicolumn{2}{|c|}{$\begin{array}{l}\text { Socio-demographic } \\
\text { Variable }\end{array}$} & \multirow{2}{*}{$\begin{array}{l}\text { Number } \\
79\end{array}$} & \multirow{2}{*}{$\begin{array}{l}\text { Percentage } \\
68.1\end{array}$} \\
\hline \multirow{2}{*}{ c cos } & Male & & \\
\hline & Female & 37 & 31.9 \\
\hline \multirow{4}{*}{$\begin{array}{l}\text { Age (in } \\
\text { years) }\end{array}$} & $16-25$ & 42 & 36.2 \\
\hline & $26-35$ & 49 & 42.2 \\
\hline & $36-45$ & 17 & 14.7 \\
\hline & $46-55$ & 8 & 6.9 \\
\hline \multirow{2}{*}{ Locality } & Urban & 70 & 60.3 \\
\hline & Rural & 46 & 39.7 \\
\hline \multirow{4}{*}{ Religion } & Hindu & 66 & 56.9 \\
\hline & Muslim & 10 & 8.6 \\
\hline & Christian & 24 & 20.7 \\
\hline & Sarna & 16 & 13.8 \\
\hline \multirow{2}{*}{ Ethnicity } & Tribal & 40 & 34.5 \\
\hline & Non tribal & 76 & 65.5 \\
\hline \multirow{3}{*}{$\begin{array}{l}\text { Marital } \\
\text { status }\end{array}$} & Married & 46 & 39.7 \\
\hline & Unmarried & 65 & 56.0 \\
\hline & $\begin{array}{l}\text { Widow/Wid } \\
\text { ower }\end{array}$ & 5 & 4.3 \\
\hline \multirow{5}{*}{$\begin{array}{l}\text { Educational } \\
\text { status }\end{array}$} & Illiterate & 13 & 11.2 \\
\hline & $\begin{array}{l}\text { Literate but } \\
\text { no formal } \\
\text { schooling }\end{array}$ & 11 & 9.5 \\
\hline & $\begin{array}{l}\text { Less than } \\
10^{\text {th }} \text { std }\end{array}$ & 15 & 12.9 \\
\hline & $\begin{array}{l}10^{\text {th }} \text { std or } \\
\text { above }\end{array}$ & 30 & 25.9 \\
\hline & $\begin{array}{l}\text { Graduate or } \\
\text { above }\end{array}$ & 47 & 40.5 \\
\hline \multirow{6}{*}{ Occupation } & Service & 33 & 28.5 \\
\hline & Business & 10 & 8.6 \\
\hline & $\begin{array}{l}\text { Daily wage } \\
\text { earner }\end{array}$ & 20 & 17.2 \\
\hline & House wife & 16 & 13.8 \\
\hline & Student & 32 & 27.6 \\
\hline & Farmer & 5 & 4.3 \\
\hline \multirow{5}{*}{$\begin{array}{l}\text { Socioecono } \\
\text { mic status } \\
\text { (as per } \\
\text { modified } \\
\text { Prasad } \\
\text { classification) }\end{array}$} & Class 1 & 25 & 21.6 \\
\hline & Class 11 & 26 & 22.4 \\
\hline & Class 111 & 33 & 28.4 \\
\hline & Class IV & 21 & 18.1 \\
\hline & Class V & 11 & 9.5 \\
\hline
\end{tabular}

\section{DISCUSSION}

ICTC is the place where HIV positive patients get care and referred to the ART for treatment to continue quality of life and HIV negative patients are taught to change their high risk behavior and make them aware about the transmission of disease and their protective measure. In our study we wanted to know the catchments area from where more number of patients are coming to ICTC and tried to know if they were involve in high risk behavior. 
The present study indicates that $68.1 \%$ of ICTC attendees were male and $31.9 \%$ were female. This gender ratio of attendee rates is less for female with national figure $(38.4 \%)$ and indicates that some barrier like stigma and discrimination which prevent female attendant to access to services provided in ICTC. ${ }^{6} 93.1 \%$ of the attendee belonged to 16-45 years of age group which is most sexually active age group is similar (92.4\%) to the study conducted in Darjeeling. ${ }^{7}$ These finding revealed that intervention should be targeted towards this vulnerable age group.

Table 2: Reason for getting tested for HIV $(n=116)$.

\begin{tabular}{|lll|}
\hline $\begin{array}{l}\text { Reason for getting tested } \\
\text { for HIV }\end{array}$ & Number & Percentage \\
\hline Employment & 7 & 6.0 \\
\hline Pregnancy & 4 & 3.4 \\
\hline $\begin{array}{l}\text { To prepare for a } \\
\text { marriage/sexual relationship }\end{array}$ & 6 & 5.2 \\
\hline $\begin{array}{l}\text { Referred by clinic for } \\
\text { sexually transmitted } \\
\text { infection }\end{array}$ & 26 & 22.4 \\
\hline $\begin{array}{l}\text { Referred due to suspected } \\
\text { HIV-related symptom }\end{array}$ & 51 & 44.0 \\
\hline $\begin{array}{l}\text { Husband/wife/partner/family } \\
\text { member tested positive }\end{array}$ & 10 & 8.7 \\
\hline Just wanted to know & 12 & 10.3 \\
\hline Total & 116 & 100 \\
\hline
\end{tabular}

The majority of the study subjects $(40.5 \%)$ were educated up to graduation and above. In the study conducted by Sharma at Ahmadabad, $38.5 \%$ of the ICTC attendees were educated up to $10^{\text {th }}$ standard. ${ }^{8}$ It is clear from studies that education provide some protection because educated people are more receptive to the information, education and communication and more able to access to services provide at ICTC.

In present study $60.3 \%$ belonged to urban area and $39.7 \%$ were from rural area. A rural preponderance was also observed among attendees in the Voluntary Counselling and Testing Centre of West Bengal in the study by Jordar et al. ${ }^{7}$ In the present study attendees married were $39.7 \%$ ,unmarried $56 \%$ and widow/widower were $4.3 \%$ is less than study conducted by Indrani Gupta. ${ }^{9}$ It is observed in present study that $28.5 \%$ were in service. This is comparable with the study by Kofi Awusabo-Asare et al in which $33.3 \%$ were in clerical occupation. ${ }^{10}$ Majority of the patients belonging to middle and lower socioeconomic class because they seek treatment in government hospital that is why their number in majority.

The leading cause for visit to ICTC were HIV related symptom (44\%) and sexually transmitted infection (22.4\%) and husband/wife/partner/family member tested positive $(8.7 \%)$.The study conducted by Sharma et al at Ahmadabad found that history or presence of high risk behavior (34\%) was the most common reason for visit to ICTC. ${ }^{8}$

\section{CONCLUSION}

About one third of the population of Jharkhand is tribal. Jharkhand is one of state in country where change in the prevalence of HIV/AIDS is seen. Awareness and life style change regarding prevention and control of HIV/AIDS should be adopted and for these epidemiology of the disease in particular geographical region with regard to sociodemographic profile must be understood. Integrated Counselling and Testing centre can establish the seropositive status among attendees. Then seropositive client can be referred for appropriate care, support and treatment and those who are seronegative should undergo proper counselling, made aware of spread and protection from disease.

\section{ACKNOWLEDGEMENTS}

We acknowledge cooperation of ICTC staff and individual who participated in the study.

\section{Funding: Not required}

Conflict of interest: None declared

Ethical approval: The study was approved by the Institutional Ethics Committee

\section{REFERENCES}

1. Ministry of Health and Family Welfare, (GOI) New Delhi: Voluntary Counselling and Testing; National AIDS Control Organization.

2. Pratisad. Come forwards and take leads stop AIDS. 2008;2.

3. Report of National Round Table Discussion and Seminar New Delhi, 2004. Organized by Oxfam GB in Collaboration with Sexual Health Resource Centre. Vol. 20. Qutab Institutional Area, New Delhi 110 016, India: Oxfam (India) Trust, C 28-29; Maximizing Access, Care Propelling Prevention in HIV/AIDS.

4. WHO, HIV/AIDS, Fact sheet No. 360, July 2015.

5. Mishra R, Diwedi S, Hassan A, Praveen K, Shaikh S, Khan MA. Socio-demographic profile of the people attending ART (Anti Retroviral Treatment) Centre: A study from SRN Hospital, Allahabad. Indian J Pre Soc Med. 2014;45(3-4).

6. Quazi SZ, Nimbarte S, Solekar D, Gaidhane A, Mudey A, Wagh V. Profile of client attending in integrated counselling and testing centre at a private rural tertiary care hospital in india. Australian Medical Journal AMJ. 2010;3(6):349-52.

7. Jordar GK, Sarkar A, Chatterjee C, Bhattachaya RN, Sarkar S, Banerjee P. Profile of attendee in VCTC of North Bengal Medical College in Darjeeling district of West Bengal. Ind $\mathrm{J}$ of Community Med. 2006;31:237-40. 
8. Sharma R. Profile of attendee for voluntary counseling and testing in the ICTC at Kesar SAL Medical College, Ahmadabad. Indian J Sex Transm Dis. 2009;30:31-6.

9. Gupta I, Shankar I. Treatment seeking Behaviour and the Willingness to pay for Antiretroviral Therapy of HIV Positive Patients in India, 2004.
10. Asare KA, Anarfi JK. Health seeking behavior of person with HIV/AIDS in Ghana. Health Transition Review. 1997;7:243-56.

Cite this article as: Haider S, Tudu L, Kashyap V. Sociodemographic profile of people attending integrated counselling and testing centre of tertiary care hospital of Jharkhand. Int J Community Med Public Health. 2016;3:319-22. 